\title{
Does Learning about Genocide Impact the Values of Young People? A Case Study from Scotland
}

\begin{abstract}
In many countries throughout the world, an integral component of education for citizenship is the development of informed values and attitudes. Within this context, issues involving topics such as an understanding of human rights, democracy, genocide, antisemitism, Islamophobia, and racism can be central to the development of more rounded human beings. There is a case for giving pupils experience in areas of learning relating to citizenship such as human rights and genocide outside the structures of the traditional subject based classroom. Such a method of learning has been attempted in the West of Scotland comprehensive, which is the subject of this study. Students in S1 (first year of secondary education $-12-13$ years of age) and in the final year associated primary (elementary schools-11-12 years of age) were taken off normal timetable for thirteen days and were engaged in a series of rich tasks and learning experiences (involving role play activities) ranging from understanding genocide, including the Holocaust and Rwanda, to UNESCO rights respecting schools initiatives to understanding poverty in the developing world to challenging intolerance.
\end{abstract}

There have been a number of studies examining whether learning about the Holocaust either as part of a study on the Second World War or as part of a citizenship programme in primary and secondary schools impacts young people's values and attitudes. ${ }^{1}$ In this case study, the project in this school was called "One World" and involved a number of activities and events for the students. The entire S1 student body-aged about 12 years and the P7 in its associated primary

1 Cf. G. Short and B. Carrington, "Unfair Discrimination: Teaching the Principles to Children of Primary School Age," Journal of Moral Education 20, no. 2 (1991): 157-77; G. Short, "Lessons of the Holocaust: A Response to Critics," Educational Review 55, no. 3 (2003): 277-87; B. Carrington and G. Short, "Holocaust Education, Anti-Racism and Citizenship,” Educational Review 47 (1997): 271-82; P. Cowan and H. Maitles, "Never Again! Does Holocaust Education Have an Effect on Pupils' Citizenship Values and Attitudes?” SEED Sponsored Research (2006): 1-72, https:// www.webarchive.org.uk/wayback/archive/20180520121056/http://www.gov.scot/Publications/ 2006/09/06133626/17; idem, "Does Addressing Prejudice and Discrimination through Holocaust Education Produce Better Citizens?” Educational Review 59, no. 2 (2007): 115-30; H. Maitles and E. McKelvie, "Why Does Wearing A Yellow Bib Make Us Different? A Case Study of Explaining Discrimination in a West of Scotland Secondary (High) School," Journal for Critical Education Policy Studies 8, no. 1 (2010): 246-61; “Continuing Professional Development," Centre for Holocaust Education, issued 2011, accessed March 15, 2017, http://www.hedp.org.uk/page_viewer. asp?page=Continuing+Professional+Development $+\&$ pid=3 [no longer available]; P. Cowan and H. Maitles, Understanding and Teaching Holocaust Education (London: SAGE, 2017).

Ә OpenAccess. () 2022 Henry Maitles, published by De Gruyter. (cc) BY-NC-ND This work is licensed under the Creative Commons Attribution-NonCommercial-NoDerivatives 4.0 International License.

https://doi.org/10.1515/9783110671971-016 
schools-was taken off timetable for thirteen days and immersed in citizenship activities. Active learning was to be at its core. The first two days involved workshops around motivation, leadership, and peer pressure issues-entitled "what it means to be human." They were led by outside agencies. Days three to six were spent in subject departments, and every department in the school took responsibility for developing citizenship from the perspective of the subject discipline. For example, mathematics developed work around percentages using the "small earth" project, designed to develop awareness of global sustainability; English focused on supporting students to research and write about inspirational figures of their choosing; science examined global warming and environmental issues. Days seven and eight involved activities around UN Convention on Human Rights, in particular a day with UNICEF speakers organizing workshops around global inequalities and human rights. Days 9 and 10 used trips and workshops outside school relating to Scotland, diversity, and racism. Days 11-13 were Genocide and Holocaust awareness, involving drama, music, the Anne Frank Trust, Rwanda, stages of genocide, Auschwitz, and workshops on Nazism. The approximately 200 students had some prior learning about the rise of the Nazis in Germany and the events leading to the Holocaust.

There are a number of reasons for why this type of learning can be of particular value. Firstly, it concentrates the learning experiences of the pupils in a way that cannot be done in the formal timetabled pattern. Secondly, it suggests that the key learning experiences in education for citizenship are best developed in a cross-curricular method, where a number (and best if a large number) of subjects have an input. Thirdly, it enables the school to comply with the best aspects of the new curriculum, in particular ideas developed through the Scottish Government Curriculum for Excellence, ${ }^{2}$ which highlights the development of responsible citizens as one of its four key capacities that schools should develop in pupils. Thus, it is felt that children need to be regarded as active, competent, and vocal members of society and that schools need to embody the values of justice, freedom, and autonomy within their institutional practice. ${ }^{3}$ Fourthly, in common with the rest of the population, young people are becoming increasingly aware of, and engaged in, single-issue politics. In particular, many children are intensely interested in issues connected with environmental sustainability and

2 Cf. Curriculum Review Group, A Curriculum for Excellence (Edinburgh: Scottish Executive, 2004).

3 Cf. P. White, "Political Education in the Early Years: The Place of Civic Values," Oxford Review of Education 25, nos. 1-2 (1999): 59 - 69; C. Burke and I. Grosvenor, The School I'd Like: Children And Young People's Reflections on An Education For The 21 $1^{\text {st }}$ Century (London: Routledge, 2003); H. Maitles, Values in Education: We're All Citizens Now (Edinburgh: Dunedin, 2005). 
global poverty, and many schools have responded to this through the establishment of eco-schools committees, fair trade groups, and a focus on development education programmes. However, media images in a global age also allow children to become exposed to many more controversial social, political, and humanitarian issues than ever before, and evidence has illustrated that pupils are keen to discuss such issues and that a programme on citizenship education needs to respond to this. ${ }^{4}$ Fifthly, there is evidence of deeper learning through these kinds of experiences. ${ }^{5}$

However, for the initiative to be of "best value," there needs to be some impact on the outlook, values, and attitudes of the young people. In the best of worlds and pupils, it will reinforce their attitudes of caring, respect, and understanding; in the real world, where some pupils don't hold these values, it is to be hoped that the programme will foster some of these and challenge aspects of their thinking. The whole raison d'etre of this approach to citizenship is summed up by this quote from a Holocaust survivor headteacher in the USA:

I am a survivor of a concentration camp. My eyes saw what no man should witness. Gas chambers built by learned engineers. Children poisoned by educated physicians. Infants killed by trained nurses. Women and babies shot and burned by high school and college graduates. So, I am suspicious of education. My request is: Help your students become more human. Your efforts must never produce learned monsters, skilled psychopaths, edu-

4 Cf. H. Maitles and R. Deuchar, “'Why Are they Bombing Innocent Iraqis?' Encouraging the Expression of Political Literacy among Primary Pupils as a Vehicle for Promoting Education for Active Citizenship," Improving Schools 7, no. 1 (2004): 97-105.

5 Cf. Burke and Grosvenor, The School I'd Like; J. Dewey, The School and Society (Chicago: University of Chicago Press, 1915); J. MacBeath and L. Moos, eds., Democratic Learning: The Challenge to School Effectiveness (London: Routledge, 2004); D. MacIntyre and D. Pedder, "The Impact of Pupil Consultation on Classroom Practice," in Consultation in the Classroom: Developing Dialogue about Teaching and Learning, ed. M. Arnot et al. (Cambridge: Pearson, 2005), 7-41; Maitles, Values in Education; H. Maitles and I. Gilchrist, "Never too Young to Learn Democracy!: A Case Study of a Democratic Approach to Learning in a Secondary Class in the West of Scotland" (paper presented at SERA, November 27-29, 2003, Perth, Scotland); idem, "Never too Young to Learn Democracy! A Case Study of a Democratic Approach to Learning in a Religious and Moral Education Secondary (RME) Class in the West of Scotland," Educational Review 58, no. 1 (2006): 67-85; A. Ritchie, Our Lives Consultation: Final Report (Edinburgh: Save the Children Scotland, 1999); J. Rudduck and J. Flutter, How To Improve Your School: Giving Pupils a Voice (London: Continuum, 2004); “'It's our Education': Young People's Views on Improving Their Schools," and "Education for Citizenship in Scotland: Perspectives of Young People," Save the Children Scotland, issued 2000 and 2001. 
cated Eichmanns. Reading, writing, arithmetic are important only if they serve to make our children more humane. ${ }^{6}$

This piece of research was designed to test this point. Has this initiative had any impact on the values and attitudes of the young people involved? Further, are there any discernible gender influences in the cohort?

To examine the impact, a values and attitudes survey was devised, building on the work of research into social values. ${ }^{7}$ It attempted, through a series of questions with a three-point Likert scale, to examine student attitudes toward diversity/multi-ethnicity; immigration/racism; and responsibility for tackling racism. The questionnaire was issued immediately before the initiative started and very soon after it ended. The pre questionnaire involved 211 students (103 male and 108 female); the post questionnaire, 207 students (101 male and 106 female). This strategy has a strength of ensuring anonymity and encouraging honest answers but meant that individual targeted follow-up interviews would not be possible. At this point a caveat must be stressed: there can be a marked change in the values of a cohort of this size with just a small number of students altering their answers leading to a large percentage shift. It was possible though to compare not just the impact of the initiative itself but also to include a gender perspective. The surveys were given to the pupils in the hall, their rights were explained to them, and objectivity was ensured.

6 H. G. Ginott, Teacher and Child: A Book for Parents and Teachers (New York: Macmillan, 1972), 317.

7 Cf. M. Angvik and B. von Borries, A Comparative European Survey on Historical Consciousness and Political Attitudes among Adolescents (Hamburg: Korber-Stiftung, 1997); C. Hahn, Becoming Political: Comparative Perspectives on Citizenship Education (Albany: State University of New York Press, 1998); R. Lister, S. Middleton, and N. Smith, Young People's Voices: Citizenship Education (Leicester: National Youth Agency, 2001); J. Torney-Purta et al., Citizenship and Education in Twenty-Eight Countries: Civic Knowledge and Engagement at Age Fourteen (Amsterdam: IEA, 2001); D. Kerr et al., Citizenship Education Longitudinal Study: Second Annual Report: First Longitudinal Survey Making Citizenship Education Real (Nottingham: DfES, 2004), https://core.ac.uk/ download/pdf/4155186.pdf; P. Whiteley, Citizenship Education Longitudinal Study Second Literature Review. Citizenship Education: The Political Science Perspective (Nottingham: DfES, 2005); Cowan and Maitles, "Never Again!" and idem, "Does Addressing Prejudice and Discrimination through Holocaust Education Produce Better Citizens?”; H. Maitles, “They’re Out to Line their Own Pockets!' Can the Teaching of Political Literacy Counter the Democratic Deficit? The Experience of Modern Studies in Scotland," Scottish Educational Review 41, no. 2 (2009): 46-61, and idem, "Citizenship Initiatives and Pupil Values: A Case Study of one Scottish School's Experience,” Educational Review 62, no. 4 (2010): 391-406; W. Schulz et al., Initial Findings from the IEA International Civic Education Study (Amsterdam: IEA, 2010). 


\section{Findings/Results}

\section{Diversity}

We asked a number of questions to assess attitudes regarding diversity, using future potential voting attitudes, primarily as the school had recently engaged in a major mock election exercise, involving these students, around the 2016 Scottish Parliamentary elections. Following the initiative, in almost all areas there was improvement and, in the cases of Jewish, Muslim, Catholic, and English people and women, substantial improvement. In the other two cases, Black and Disabled people, it was virtually the same before and after the initiative. Attitudes toward gay people, whilst more tolerant after than before the programme, were lower overall. This supported our findings, ${ }^{8}$ which found that students in transition from primary 7 to secondary 1 were more tolerant toward minority groups after learning about the Holocaust.

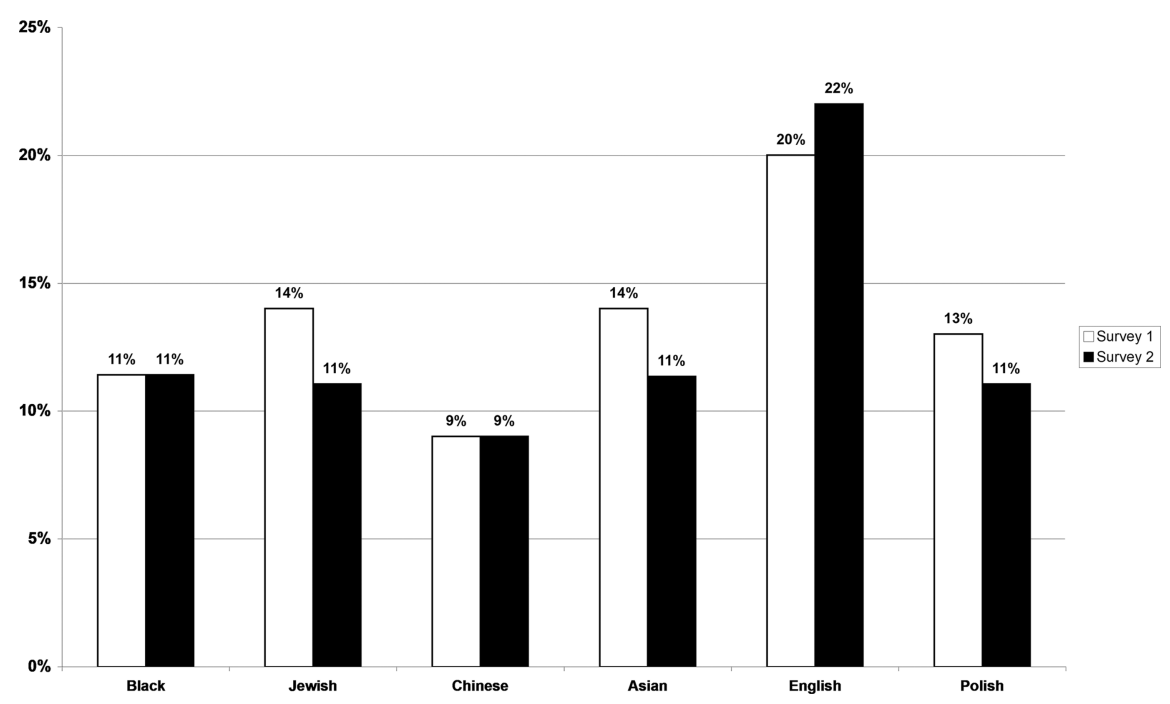

Table 1: "I think there are too many...in Scotland."

8 Cowan and Maitles, “Never Again!”; idem, “Does Addressing Prejudice and Discrimination through Holocaust Education Produce Better Citizens?” and idem, Teaching Controversial Issues in the Classroom: Key Issues and Debates (London: Continuum, 2013). 


\section{Multi Ethnicity}

Welcomingly, in most areas the results suggest a positive general outlook. Attitudes toward Jews, Asians, and Poles improved over the initiative; but attitudes toward Blacks and Chinese stayed constant. Worst overall were the attitudes toward the English. They were the most negative in both surveys and actually were less positive after the initiative than before.

The picture was more complex with regards to immigration/asylum seekers. Whilst the students' attitudes toward full rights for black people improved slightly, and there was some increased support for refugees, there was no increase in positive welcoming attitudes toward asylum seekers and economic immigrants, although we were not in a position to find out whether students understood the difference between the two categories. Clearly, the impact of both the recession and media and political calls for "British jobs for British workers" and supposed concerns of immigration into Britain, particularly fuelled by the BREXIT debate, will be hard for school education programmes to challenge, if we wished to do so. More than $80 \%$ in both surveys felt that it was wrong to make racist jokes.

Welcomingly, there was a reduction in hostility toward Jews, but worryingly the numbers who thought there were too many Jews in Scotland only reduced by $3 \%$ to $11 \%$. And this despite the fact that Jews in Scotland only comprise some $0.1 \%$ of the population (incidentally a similar percentage to Jews in Germany in 1933), and there were no Jews in this cohort. This area clearly needs some further investigation, and we can only hypothesise about this in the context of the survey. Firstly, there can be antisemitism where there are few or no Jews. There is a negative perception of Jews that can be very pervasive. ${ }^{9}$ Linked to this is a necessity to discuss Holocaust education in a way that raises antisemitism. Maitles and Cowan found that many teachers used the word racism instead of the word antisemitism to discuss the Holocaust. ${ }^{10}$ It is important to use the word antisemitism or it can lead to confusion for students.

9 Cf. G. Short and B. Carrington, "Antisemitism and the Primary School: Children's Perceptions of Jewish Culture and Identity,” Research in Education 54 (1995): 14-24; Cowan and Maitles, "Does Addressing Prejudice and Discrimination through Holocaust Education Produce Better Citizens?”

10 Cf. Cowan and Maitles, "Does Addressing Prejudice and Discrimination through Holocaust Education Produce Better Citizens?” and idem, Teaching Controversial Issues in the Classroom. 


\section{Responsibility for Racism}

The attempt here was to gauge the attitudes toward both collective and individual responsibility for dealing with racism.

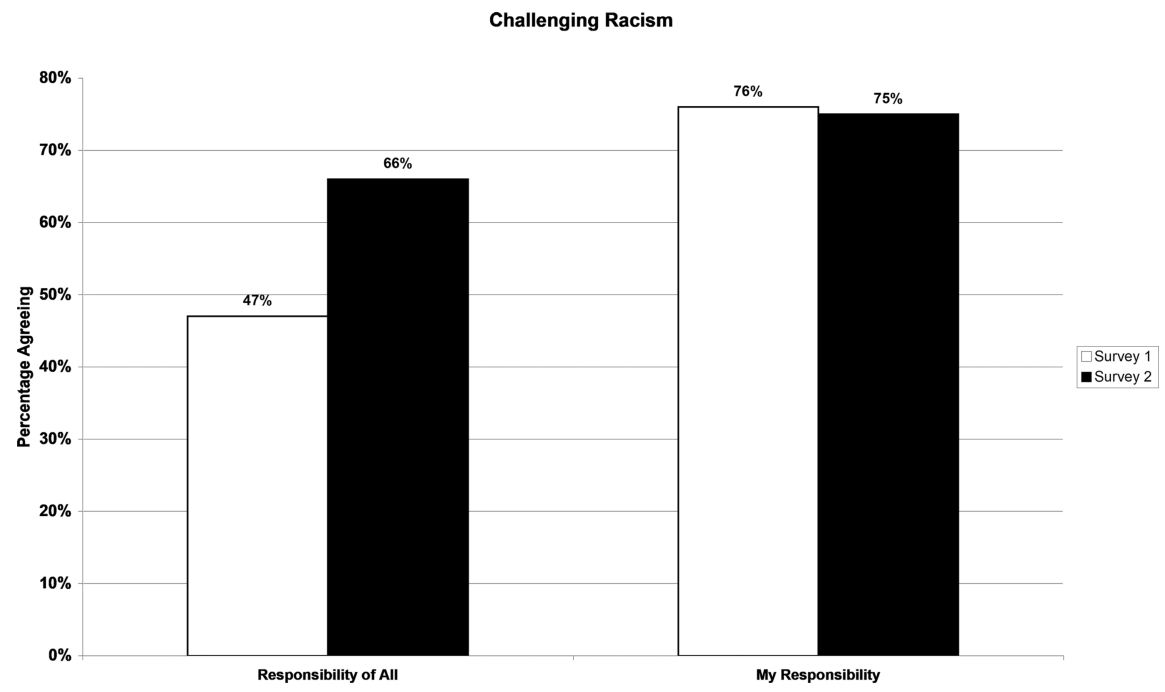

Table 2: Challenging racism.

The results are positive. In particular, a large increase in the percent believing that society as a whole should challenge racism and a welcomingly high response to individual responsibility in both surveys. It is feasible to suggest that the $1 \%$ drop in individual responsibility can be explained by one pupil thinking the two areas were mutually exclusive. But, because of anonymity, this is impossible to confirm.

There can be issues when examining this kind of evidence of Holocaust education and citizenship education as to whether one sees the glass as half full or half empty. For example, should we be pleased that over three-quarters of the students felt that they had personal responsibility for challenging racism or worried that $25 \%$ think that racism has nothing to do with them? Overall, there is evidence of a general improvement in values and attitudes after the students undertook the initiative, although in most issues (except with attitudes toward gay and English people) there was a high(ish) level before the citizenship initiative. Nonetheless, the fact that in the vast majority of categories, students were more positive after than before suggests that these initiatives were worthwhile. 
However, the research can be of best value as we try to evaluate the development of citizenship ideas in young people. The involvement of many subjects in the school can take Holocaust education and citizenship education out of a potential isolation and place its understanding at the heart of the school. This allows for cross-curricular/active learning experiences for deeper learning and more interesting (and potentially longer lasting) learning experiences. For example in their genocide awareness days, there was an observable and powerful impact on the students of the speaker from Rwanda and the workshop by two senior students at the school outlining their experiences of Auschwitz as part of the Lessons from Auschwitz Programme, the Anne Frank workshops, and diverse and active music and drama. We can surmise that this helped their understanding of some of the issues, reflected in the results of the survey reported above.

\section{Other Areas}

There was an increase from $25 \%$ to $35 \%$ of those who believe that the "world would be a better place if more women were world leaders" and an increase from $76 \%$ to $79 \%$ of those who thought that "we should end religious segregation in schools." 11 Maitles in his sample of approximately 1,600 15- to 16-year-old students found that $25 \%$ agreed with the point about woman leaders, but in terms of ending religious segregation in schools only $43 \%$ agreed. ${ }^{12}$ Whether the older age of the Maitles sample was the issue for this divergence or whether the fact that the cohort in the survey of the present paper was all from a nondenominational school, and this had an impact, would need further investigation.

\section{Gender Issues}

The clearest differences are between the attitudes of boys and girls in our sample. In every index, girls were more progressive in terms of citizenship values than boys (Tables 3 to 7).

11 It should be noted that some $97 \%$ of Scots children go to state funded comprehensive schools and that these schools are non-denominational or Catholic, with one Jewish primary (elementary) school.

12 Cf. Maitles, “They’re Out to Line their Own Pockets!” 
Full Equality for Gay People

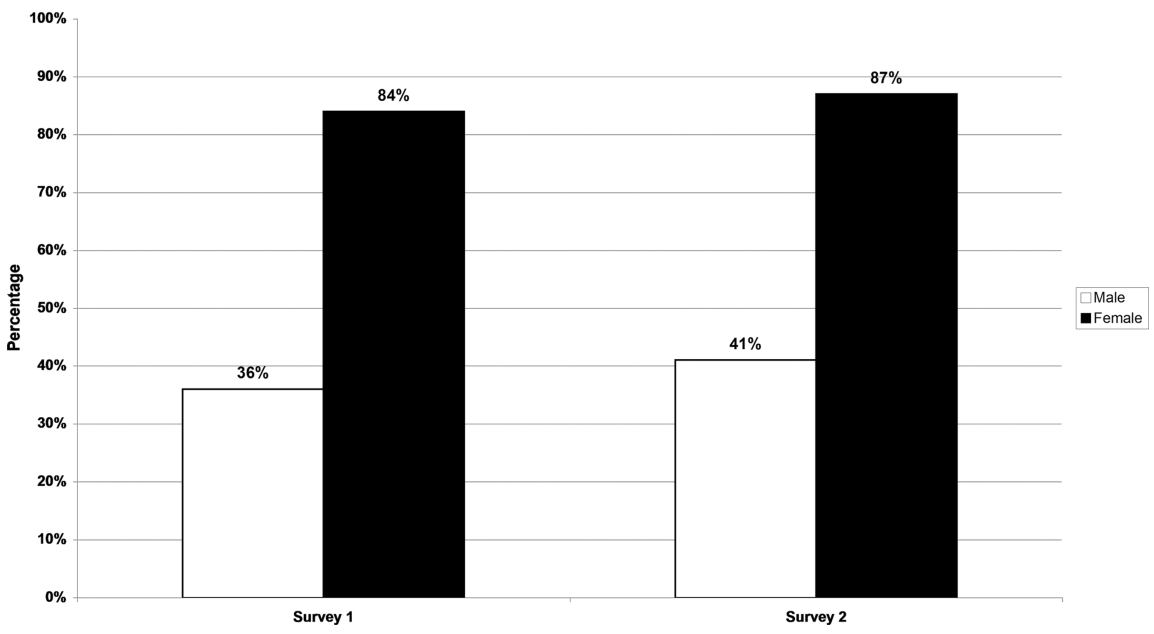

Table 3: Full equality for gay people.

Too Many English People in Scotland

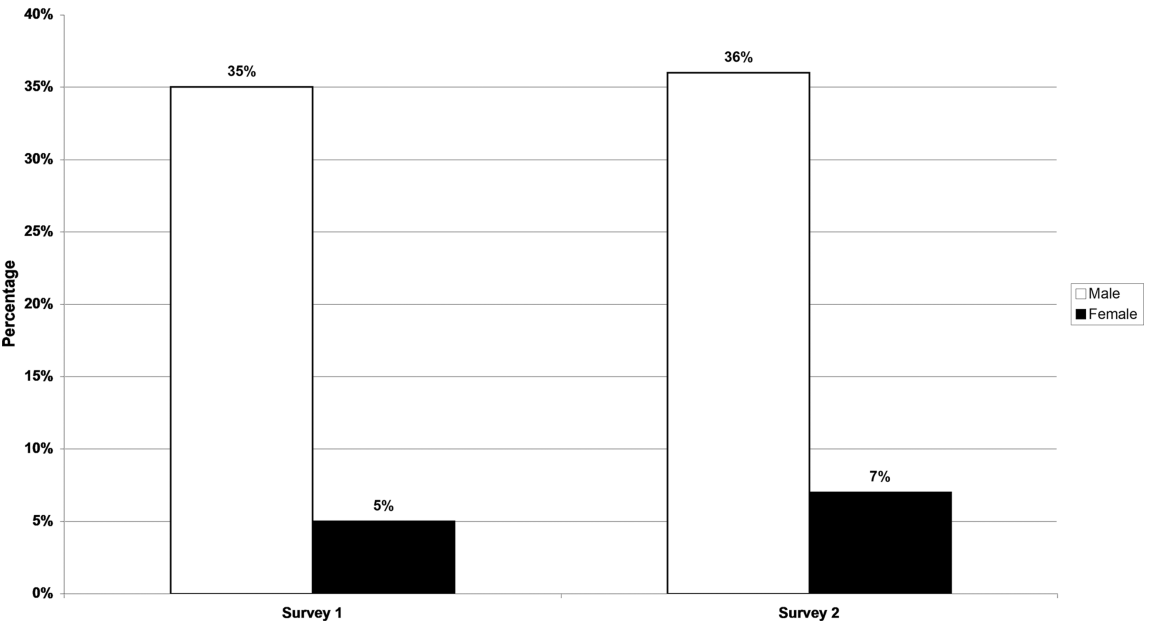

Table 4: Too many English people in Scotland. 
I would be as likely to vote for an English person as a Scottish person for the Scottish Parliament

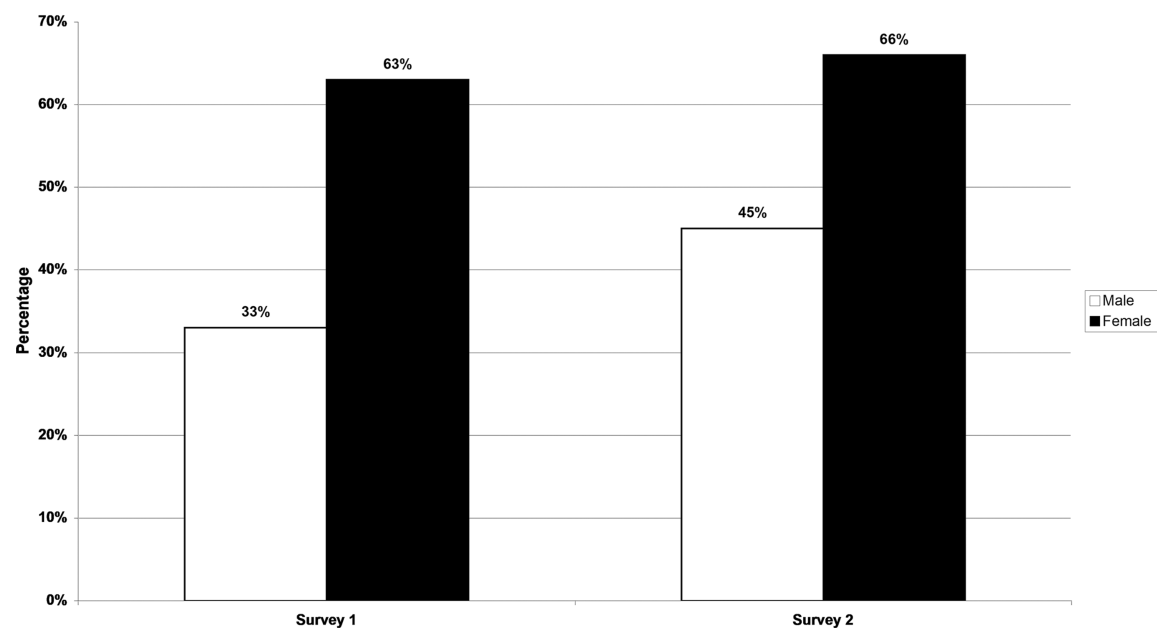

Table 5: English people in Scottish Parliament.

I think we should reduce Immigration into Scotland

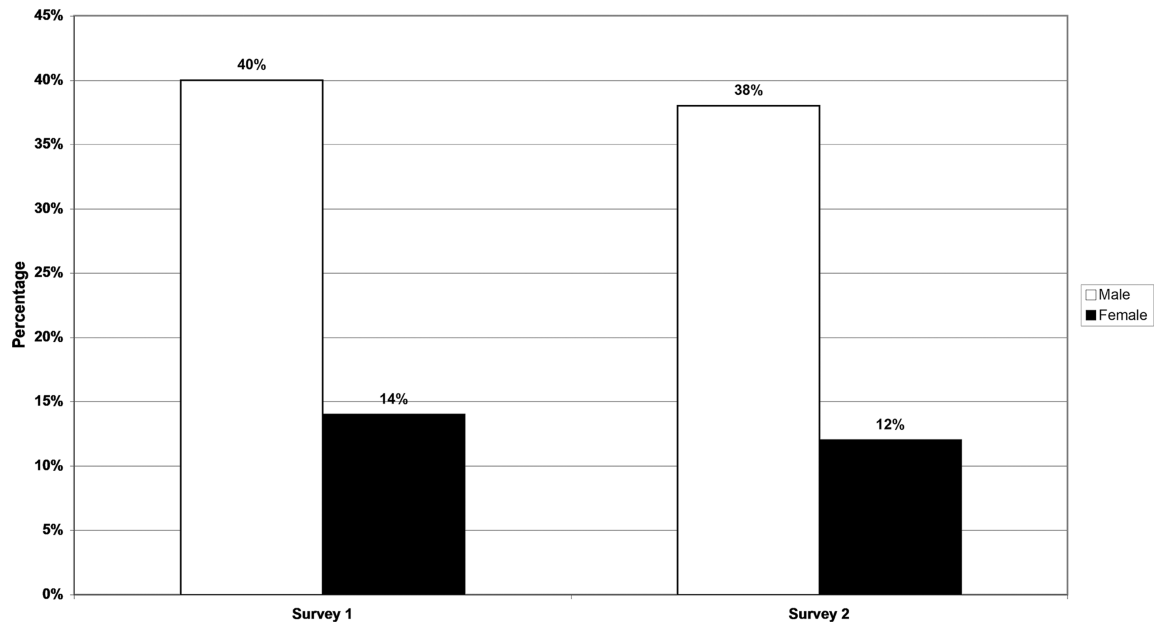

Table 6: Immigration to Scotland. 
I think we should try to buy Fairtrade Goods

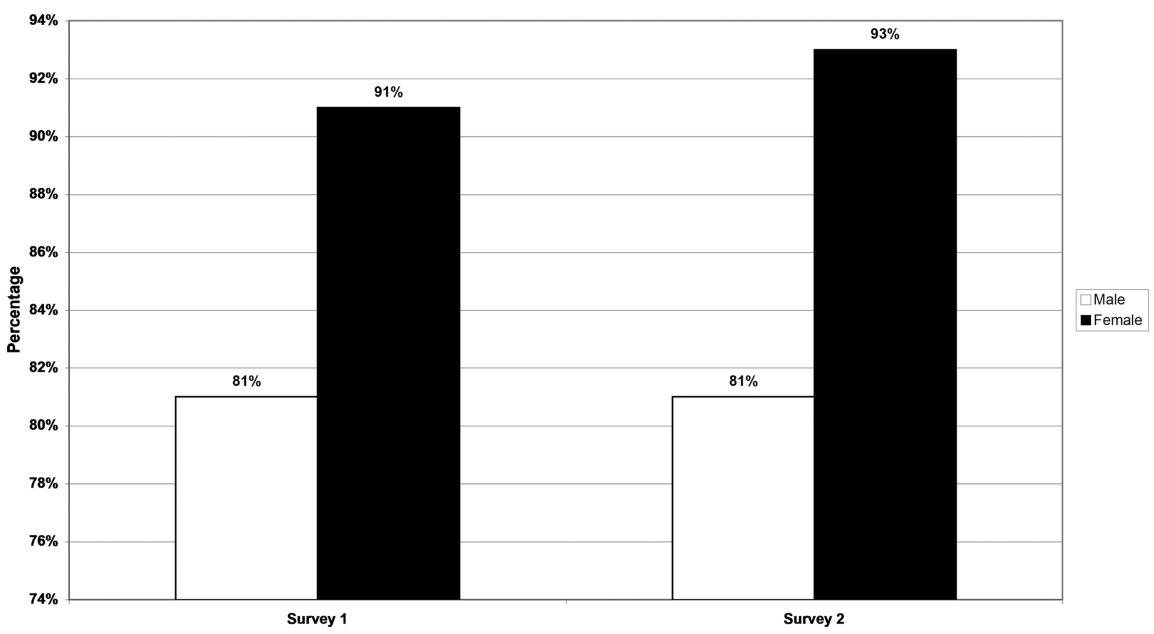

Table 7: Fairtrade goods.

It is well documented that there is a gender attainment gap with recent official reports and statistics across the UK, ${ }^{13}$ showing that girls are continuing to outperform boys in academic achievement, even if the difference has ceased to grow. The statistics are similar internationally in, for example, Australia ${ }^{14}$ and in Spain..$^{15}$ The PISA surveys from 2003 onward found boys ahead (marginally) in math but well behind in reading; there was no significant difference in science. One very interesting point was that boys showed a greater range of performance in problem solving than girls; more boys were among both the higher and the lower performers. Much of the research puts this down to maturity, indeed

13 Cf. e.g. Department for Education and Skills, Gender and Education: The Evidence on Pupils in England (Nottingham: DfES, 2007), https://dera.ioe.ac.uk/6616/8/rtp01-07_Redacted.pdf; “SQA Examination Results in Scottish Schools, 2007/08," Scottish Government, issued 2008, accessed December 1, 2017, https://www.webarchive.org.uk/wayback/archive/20160121070437/ http://www.gov.scot/Publications/2008/09/10154841/1; E. Busby, “GCSE Results 2017: Girls Maintain Lead over Boys despite New Linear Exams,” Times Educational Supplement, August 24, 2017, https://www.tes.com/news/gcse-results-2017-girls-maintain-lead-over-boys-despite-new-linearexams.

14 Cf. S. J. Gibb et al., "Gender Differences in Educational Achievement to age 25," Australian Journal of Education 52, no. 1 (2008): 63-80.

15 Cf. O. Marcenaro-Gutierrez et al., “Gender Differences in Adolescents' Academic Achievement," Young 26, no. 3 (2018): 250 -70. 
concepts of masculinity, and different learning styles of boys and girls. ${ }^{16}$ Linked to this, it can be argued that the type of examinations in the UK, many of which involve significant coursework, are better suited for girls as this type of work fits better with their maturity and learning styles. ${ }^{17}$ As regards disaffection and dispositions, the Longitudinal Study of Young People in England research suggested that there was not a great deal of difference in the ways that boys and girls viewed school but that there was a much higher chance of boys disaffection resulting in exclusion; boys accounted for $80 \%$ of exclusions.

In general, thus, in many indices girls are outperforming boys. However, when it comes to trying to find out whether there is a gender difference in the values and attitudes of adolescents, the research evidence is much weaker. Large scale comparative attitudes surveys ${ }^{18}$ do provide valuable information about values and attitudes but don't provide a gender dimension. Prough and Postic found that girl adolescents in the USA were more intolerant of racists and homophobia and more positive toward social equality than adolescent males. ${ }^{19}$ Soule and Nairne found that girls are slightly more interested in politics, more participative, and are more politically tolerant than boys. ${ }^{20}$ Similarly

16 Cf. M. Arnot et al., Recent Research on Gender and Educational Performance (London: The Stationary Office, 1998); R. Bray et al., Can Boys Do Better? (Leicester: Secondary Heads Association, 1997); C. Forde et al., Professional Development, Reflection and Enquiry (London: Paul Chapman, 2006); A. MacDonald et al., Boys' Achievement, Progress, Motivation and Participation: Issues Raised by Recent Literature (Slough: NFER, 1999); S. Machin and S. McNally, "Gender and Student Achievement in English Schools," Oxford Review of Economic Policy 21, no. 3 (2005): 357-72; E. Millard, Differently Literate: Boys, Girls and the Schooling of Literacy (London: Falmer, 1997); J. Oakhill and A. Petrides, "Sex Differences in the Effects of Interest on Boys' and Girls' Reading Comprehension,” British Journal of Psychology 98, no. 2 (2007): 223-35; L. Sukhnandan et al., An Investigation into Gender Differences in Achievement: Phase 2: School and Classroom Strategies (Slough: NFER, 2000).

17 Cf. C. Gipps and P. Murphy, Equity in the Classroom: Towards Effective Pedagogy for Girls and Boys (London: Routledge, 1994); J. Powney, Gender and Attainment: A Review (Glasgow: The SCRE Centre, 1996); G. Stobart and J. White, Differential Performance in Examinations at 16+: English and Mathematics: Final Report (London: School Examinations and Assessment Council, 1992).

18 Cf. e.g. Hahn, Becoming Political; Torney-Purta et al., Citizenship and Education in TwentyEight Countries.

19 Cf. E. Prough and R. Postic, “Today's Dick and Jane: A Look Into the Levels of Political Tolerance of Adolescents in Public and Religious High School Environments" (paper presented at the 2008 Annual Meeting of the Midwest Political Science Association, April 3-6, 2008, Chicago, IL, USA).

20 Cf. S. Soule and J. Nairne, "Are Girls Checking Out? Gender and Political Socialization in Transitioning Democracies” (paper presented at the Midwestern Political Science Meeting, 
Badger et al. measuring gender preferences in terms of caring and personal values, found girls more positive. ${ }^{21}$ Contrastingly, Flanagan and Tucker found no consistent gender pattern in adolescents' political attributions. ${ }^{22}$ Similarly, drawing on interviews and observations with high school students in the USA, Morimoto argued that boys' and girls' explanations for participating are strikingly similar. ${ }^{23}$ However, all these studies were for the USA; there is little of this type of evidence from Britain, and this was one of the areas we wished to examine. British studies, for example, Archer ${ }^{24}$ and Archer and Francis examine the values of Muslim boys in the former and British-Chinese in the latter. Whilst most of the evidence is ethnic in nature and shows a generalised racism in schools, a key finding is of a generalised male sexism and a macho "laddish" outlook that impinges negatively on their values. On occasions, this has led to some schools opting for single gender classes and "boy calming" initiatives, although these types of responses have been questioned and criticized in research by Lingard et al. ${ }^{25}$ Maitles and Cowan, in their study of Holocaust education in high schools, found that their adolescents (aged 15 to 16 years) showed significant gender differences in terms of values and attitudes. The study reported here finds similarity with the research discussed above in that girls are much more understanding and tolerant in general than boys. In the tables above (3 to 7) we find clear evidence to back this up. ${ }^{26}$

April 19-23, 2006, Chicago, IL, USA), https://www.civiced.org/pdfs/research/Gender AndPolitical.pdf.

21 Cf. K. Badger et al., “Age and Gender Differences in Value Orientation among American Adolescents," Adolescence 33 (1998): 27-52.

22 Cf. C. Flanagan and C. J. Tucker, "Adolescents' Explanations for Political Issues: Concordance With Their Views of Self and Society,” Developmental Psychology 35, no. 5 (1999): 11981209.

23 Cf. S. A. Morimoto, "Democracy for Teens: Gender and Becoming a Good Citizen” (paper presented at the annual meeting of the American Sociological Association, August 11, 2007, New York City, USA).

24 Cf. L. Archer, Race, Masculinity and Schooling: Muslim Boys and Education (Berkshire: Open University Press, 2003); L. Archer and B. Francis, Understanding Minority Ethnic Achievement: Race, Gender, Class and 'Success' (London: Routledge, 2007).

25 Cf. B. Lingard et al., Boys and Schooling: Beyond Structural Reform (London: Palgrave Macmillan, 2008).

26 Cf. Maitles, "Citizenship Initiatives and Pupil Values.” 


\section{Conclusions}

There is a real debate about the pedagogy surrounding Holocaust education and its relationship to citizenship education. Where the Holocaust is embedded in the curriculum, generally through the subject discipline of history, there is the clear advantage of learning about it-albeit with the time constraints and lack of interdisciplinarity as key drawbacks. In curriculums where the Holocaust is taught as part of a citizenship education programme, there can be interdisciplinary activities and learning related to the citizenship areas inherent in Holocaust education, with the proviso that the historical events leading up to the Holocaust must play a central role. In reality, there is no dichotomy between the two. It is not in the interests of developing Holocaust education to argue that it can only be adequately or properly done through history. Where we can mix the historical knowledge of the events with a strong focus on its evils and that this is the end to which behaviours, such as stereotyping and racism, can lead to, young people learn both about and from the Holocaust. Finally, our research suggested that even after learning about the Holocaust, some $11 \%$ of the sample agreed that there were too many Jews in Scotland. As we discuss above, this has clear implications for pedagogy.

Henry Maitles is Emeritus Professor of Education at the University of the West of Scotland. He researches and teaches in the area of citizenship, human rights and values, the Holocaust and genocide, and in particular the impact of citizenship initiatives in the schools. He has authored or co-authored four books, the most recent being Understanding and Teaching Holocaust Education. This was awarded the CiCea/Jean Monnet citizenship network best book award in 2018 and cited in the most recent UNESCO report on "Combatting Anti-Semitism through Education."

\section{References}

Angvik, Magne, and Bodo von Borries. A Comparative European Survey on Historical Consciousness and Political Attitudes among Adolescents. Hamburg: Korber-Stiftung, 1997.

Archer, Louise. Race, Masculinity and Schooling: Muslim Boys and Education. Berkshire: Open University Press, 2003.

Archer, Louise, and Becky Francis. Understanding Minority Ethnic Achievement: Race, Gender, Class and 'Success.' London: Routledge, 2007.

Arnot, Madeleine, John Gray, Mary James, Jean Rudduck, and Gerard Duveen. Recent Research on Gender and Educational Performance. London: The Stationary Office, 1998. 
Badger, Kimberly, Rebecca Simpson Craft, and Larry Jensen. “Age and Gender Differences in Value Orientation among American Adolescents.” Adolescence 33 (1998): 27-52.

Bray, Robert, Christopher Gardner, and Nigel Parsons. Can Boys Do Better? Leicester: Secondary Heads Association, 1997.

Burke, Catherine, and Ian Grosvenor. The School l'd Like: Children And Young People's Reflections on An Education For The 21 $1^{\text {st }}$ Century. London: Routledge, 2003.

Busby, Eleanor. "GCSE Results 2017: Girls Maintain Lead over Boys despite New Linear Exams.” Times Educational Supplement, August 24, 2017. https://www.tes.com/news/ gcse-results-2017-girls-maintain-lead-over-boys-despite-new-linear-exams.

Carrington, Bruce, and Geoffrey Short. "Holocaust Education, Anti-Racism and Citizenship." Educational Review 47 (1997): 271-82.

Centre for Holocaust Education. “Continuing Professional Development.” Issued 2011. Accessed March 15, 2017. http://www.hedp.org.uk/page_viewer.asp?page=Continuing +Professional+Development+\&pid=3. [No longer available.]

Cowan, Paula, and Henry Maitles. "Does Addressing Prejudice and Discrimination through Holocaust Education Produce Better Citizens?” Educational Review 59, no. 2 (2007): $115-30$.

Cowan, Paula, and Henry Maitles. "Never Again! Does Holocaust Education Have an Effect on Pupils' Citizenship Values and Attitudes?” SEED Sponsored Research (2006): 1-72. https://www.webarchive.org.uk/wayback/archive/20180520121056/http://www.gov.scot/ Publications/2006/09/06133626/17.

Cowan, Paula, and Henry Maitles. "Policy and Practice of Holocaust Education in Scotland." Prospects 40, no. 2 (2010): 257-72.

Cowan, Paula, and Henry Maitles, eds. Teaching Controversial Issues in the Classroom Key Issues and Debates. London: Continuum, 2013.

Cowan, Paula, and Henry Maitles. Understanding and Teaching Holocaust Education. London: SAGE, 2017.

Curriculum Review Group. A Curriculum for Excellence. Edinburgh: Scottish Executive, 2004.

Dewey, John. The School and Society. Chicago: University of Chicago Press, 1915.

Department for Education and Skills. Gender and Education: The Evidence on Pupils in England. Nottingham: DfES, 2007. https://dera.ioe.ac.uk/6616/8/rtp01-07_Redacted.pdf.

Flanagan, Constance, and Corinna Jenkins Tucker. "Adolescents' Explanations for Political Issues: Concordance With Their Views of Self and Society." Developmental Psychology 35, no. 5 (1999): $1198-1209$.

Forde, Christine, Margery McMahon, Alastair McPhee, and Fiona Patrick. Professional Development, Reflection and Enquiry. London: Paul Chapman, 2006.

Gibb, Sheree J., David M. Fergusson, and L. John Horwood. "Gender Differences in Educational Achievement to age 25." Australian Journal of Education 52, no. 1 (2008): 63-80.

Ginott, Haim G. Teacher and Child: A Book for Parents and Teachers. New York: Macmillan, 1972.

Gipps, Caroline, and Patricia Murphy. Equity in the Classroom: Towards Effective Pedagogy for Girls and Boys. London: Routledge, 1994.

Hahn, Carole. Becoming Political: Comparative Perspectives on Citizenship Education. Albany: State University of New York Press, 1998. 
Kerr, David, Eleanor Ireland, Joana Lopes, Rachel Craig, and Elizabeth Cleaver. Citizenship Education Longitudinal Study: Second Annual Report: First Longitudinal Survey Making Citizenship Education Real. Nottingham: DfES, 2004. https://core.ac.uk/download/pdf/ 4155186.pdf.

Lingard, Bob, Wayne Martino, and Martin Mills. Boys and Schooling: Beyond Structural Reform. London: Palgrave Macmillan, 2008.

Lister, Ruth, Sue Middleton, and Noel Smith. Young People's Voices: Citizenship Education. Leicester: National Youth Agency, 2001.

MacBeath, John, and Lejf Moos, eds. Democratic Learning: The Challenge to School Effectiveness. London: Routledge, 2004.

MacDonald, Annette, Pauline Benefield, and Lesley Saunders. Boys' Achievement, Progress, Motivation and Participation: Issues Raised by Recent Literature. Slough: NFER, 1999.

Machin, Stephen, and Sandra McNally. "Gender and Student Achievement in English Schools." Oxford Review of Economic Policy 21, no. 3 (2005): 357-72.

MacIntyre, Donald, and David Pedder. "The Impact of Pupil Consultation on Classroom Practice." In Consultation in the Classroom: Developing Dialogue about Teaching and Learning, edited by Madeleine Arnot, Donald McIntyre, David Pedder, and Diane Reay, 7-41. Cambridge: Pearson, 2005.

Maitles, Henry. "Citizenship Initiatives and Pupil Values: A Case Study of one Scottish School's Experience." Educational Review 62, no. 4 (2010): 391- 406.

Maitles, Henry. "They're Out to Line their Own Pockets!' Can the Teaching of Political Literacy Counter the Democratic Deficit? The Experience of Modern Studies in Scotland." Scottish Educational Review 41, no. 2 (2009): 46-61.

Maitles, Henry. Values in Education: We're All Citizens Now. Edinburgh: Dunedin, 2005.

Maitles, Henry, and Ross Deuchar. “'Why Are they Bombing Innocent Iraqis?' Encouraging the Expression of Political Literacy among Primary Pupils as a Vehicle for Promoting Education for Active Citizenship." Improving Schools 7, no. 1 (2004): 97-105.

Maitles, Henry, and Isabel Gilchrist. "Never too Young to Learn Democracy!: A Case Study of a Democratic Approach to Learning in a Secondary Class in the West of Scotland." Paper presented at SERA, November 27-29, 2003, Perth, Scotland.

Maitles, Henry, and Isabel Gilchrist. "Never too Young to Learn Democracy! A Case Study of a Democratic Approach to Learning in a Religious and Moral Education (RME) Secondary Class in the West of Scotland." Educational Review 58, no. 1 (2006): 67-85.

Maitles, Henry, and Erin McKelvie. "Why Does Wearing A Yellow Bib Make Us Different? A Case Study of Explaining Discrimination in a West of Scotland Secondary (High) School." Journal for Critical Education Policy Studies 8, no. 1 (2010): 246-61.

Marcenaro-Gutierrez, Oscar, Luis Lopez-Agudo, and Miguel Angel Ropero-Garcia. "Gender Differences in Adolescents’ Academic Achievement.” Young 26, no. 3 (2018): 250-70.

Millard, Elaine. Differently Literate: Boys, Girls and the Schooling of Literacy. London: Falmer, 1997.

Morimoto, Shauna A. "Democracy for Teens: Gender and Becoming a Good Citizen." Paper presented at the Annual Meeting of the American Sociological Association, August 11, 2007, New York City, USA.

Oakhill, Jane, and Alison Petrides. "Sex Differences in the Effects of Interest on Boys' and Girls' Reading Comprehension.” British Journal of Psychology 98, no. 2 (2007): 223-35. Powney, Janet. Gender and Attainment: A Review. Glasgow: The SCRE Centre, 1996. 
Programme for International Student Assessment (PISA). "Assessing Scientific, Reading and Mathematical Literacy: A Framework for PISA 2006.” Issued 2006. https://www.oecd-ili brary.org/docserver/9789264026407-en.pdf?expires=1611663630\&id=id\&accname= guest\&checksum=713F16A059CAECD527F1410D952D2DE3.

Programme for International Student Assessment (PISA). "The PISA 2003 Assessment Framework." Issued 2003. http://www.oecd.org/education/school/pro grammeforinternationalstudentassessmentpisa/33694881.pdf.

Programme for International Student Assessment (PISA). "PISA 2015 Assessment and Analytical Framework." Issued 2015. https://www.oecd-ilibrary.org/docserver/ 9789264281820-en.pdf?expires=1611663674\&id=id\&accname=guest $\&$ checksum $=$ 03C78D3ACA666D44546E1F36D119DA2B.

Prough, Elizabeth, and Robert Postic. "Today's Dick and Jane: A Look Into the Levels of Political Tolerance of Adolescents in Public and Religious High School Environments." Paper presented at the 2008 Annual Meeting of the Midwest Political Science Association, April 3-6, 2008, Chicago, IL, USA.

Ritchie, Alison. Our Lives Consultation: Final Report. Edinburgh: Save the Children Scotland, 1999.

Rudduck, Jean, and Julia Flutter. How To Improve Your School: Giving Pupils a Voice. London: Continuum, 2004.

Save the Children Scotland. “It's our Education': Young People's Views on Improving Their Schools.” Issued 2000.

Save the Children Scotland. "Education for Citizenship in Scotland: Perspectives of Young People.” Issued 2001.

Schulz, Wolfram, John Ainley, Julian Fraillon, David Kerr, and Bruno Losito. Initial Findings from the IEA International Civic Education Study. Amsterdam: IEA, 2010.

Scottish Government. "SQA Examination Results in Scottish Schools, 2007/08." Issued 2008. Accessed December 1, 2017. https://www.webarchive.org.uk/wayback/archive/ 20160121070437/http://www.gov.scot/Publications/2008/09/10154841/1.

Short, Geoffrey. "Lessons of the Holocaust: A Response to Critics." Educational Review 55 , no. 3 (2003): 277-87.

Short, Geoffrey, and Bruce Carrington. "Antisemitism and the Primary School: Children's Perceptions of Jewish Culture and Identity." Research in Education 54 (1995): $14-24$.

Short, Geoffrey, and Bruce Carrington. "Unfair Discrimination: Teaching the Principles to Children of Primary School Age." Journal of Moral Education 20, no. 2 (1991): 157-77.

Soule, Suzanne, and Jennifer Nairne. "Are Girls Checking Out? Gender and Political Socialization in Transitioning Democracies." Paper presented at the Midwestern Political Science Meeting, April 19-23, 2006, Chicago, IL, USA. https://www.civiced.org/pdfs/re search/GenderAndPolitical.pdf.

Stobart, Gordon, and John White. Differential Performance in Examinations at 16+: English and Mathematics: Final Report. London: School Examinations and Assessment Council, 1992.

Sukhnandan, Laura, Barbara Lee, and Sara Kelleher. An Investigation into Gender Differences in Achievement: Phase 2: School and Classroom Strategies. Slough: NFER, 2000.

Torney-Purta, Judith, Rainer Lehmann, Hans Oswald, and Wolfram Schulz. Citizenship and Education in Twenty-Eight Countries: Civic Knowledge and Engagement at Age Fourteen. Amsterdam: IEA, 2001. 
White, Patricia. "Political Education in the Early Years: The Place of Civic Values." Oxford Review of Education 25, nos. 1-2 (1999): 59-69.

Whiteley, Paul. Citizenship Education Longitudinal Study Second Literature Review. Citizenship Education: The Political Science Perspective. Nottingham: DfES, 2005. 